\title{
LIVING MATERIAL AS A BUILDING FAÇADE: THE EFFECT OF MOSS GROWTH TOWARD MECHANICAL PERFORMANCE ON PRE-VEGETATED CONCRETE PANELS
}

\author{
Intan Chairunnisa $^{*}$, Dalhar Susanto ${ }^{1}$ \\ ${ }^{1}$ Department of Architecture, Faculty of Engineering, Universitas Indonesia, Kampus UI Depok, \\ Depok 16424, Indonesia
}

(Received: March 2018 / Revised: June 2018 / Accepted: October 2018)

\begin{abstract}
The increasing construction of tall buildings in Indonesia has led to the reduction of green areas and the increase use of building materials such as concrete panels. This research sees the potential of building façades created by using concrete panels as media for growing plants to replace those green areas that have decreased. The plants that are used in this research are selected based on the climatic conditions of tropical countries in Indonesia. The plants that are chosen are fast growing, require less maintenance, and are considered to be suitable for cementitious materials. A previous study has found that bryophyte moss meets those criteria. This research compares the performance of pre-vegetated and non-pre-vegetated concrete panels by investigating compressive strength through laboratory experiments. Three mixes of concrete, three moss species, and three concrete surfaces were examined with 9 panels, 27 cube samples, and 9 cube controls. The study contributes to a growing body of research on the sustainability of building façades in which further investigation is needed.
\end{abstract}

Keywords: Living material; Precast concrete panel; Pre-vegetated concrete panel

\section{INTRODUCTION}

Building development has been increasing to fulfill human needs and activities. A broad range of housing, apartment, retail, and skyscraper developments in the world are mostly constructed with concrete. Large-scale urban development has affected vegetation areas and their properties (trees, shrubs, grasses, etc.) as these green areas give way to concrete blocks. Urban development reduces the availability of green areas (Kiran et al., 2005). Hardened areas in buildings such as roofs, walls, balconies, and other areas can be transformed into plant vegetation areas and replace the grounded vegetation into a more sustainable building (Johnston $\&$ Newton, 1993). Plants that are grown on, up, or against internal or external walls of buildings or as freestanding structures are called vertical greenery (Mansor et al., 2017). One building in Newbury changed its façade from basic concrete (which is considered dull and unattractive) to vertical greenery, positively improving the aesthetic performance of the building and improving air quality (Ord, 2017). To create successful vertical greenery, the plant must be chosen carefully. Several plants hold their own soil or artificial growing mediums, which most of these systems need for more complex façade design (Rakhshandehroo et al., 2015). Other plants grow on the surfaces of building façades as hybrid materials of living things and an object called living material. A plant which does not require special care is moss. Moss can grow on wood panels without any light, water, or specific care (Garty, 2003).

\footnotetext{
*Corresponding author's email: intan.chairunnisa61@ui.ac.id, Tel: +62-217863512, Fax: +62-217863514 Permalink/DOI: https://doi.org/10.14716/ijtech.v9i6.2445
} 
Moss is the second largest plant group after tall plants. The number of mosses is approximately 18,000 species worldwide and 1,500 species in Indonesia. Indonesia is a tropical country, characterized by high rainfall and year-round sunshine, allowing various types of moss to grow. The vital roles of moss in environmental ecology include contributions to the nutrient-andwater cycle, the carbon-exchange cycle, and protecting the environment (Waldi, 2017). On the other hand, moss that grows on building materials tends to cause deterioration and damage to the material (Lisci et al., 2003). Other studies show that moss can provide benefits for historic buildings, for example protecting images of carved petroglyphs, moisture regulators for fragile stone materials, etc. (Chiari \& Cossio, 2002) In these studies, it was found that moss has the potential to be used as a plant that is useful for buildings, so it is possible to be developed as research.

This study aimed to engineer moss growth on the surface of precast concrete panels and analyze the mechanical performance of these panels. The moss growth was calculated to examine the successful growth.

\section{LITERATURE STUDY}

Materials in architecture visualize design concepts and ideas into forms that influence spatial experience and provide a lively building (Farelly, 2009). Building materials come from natural materials such as wood, bamboo, rattan, etc., which can be directly used in building construction. Building materials are also derived from earth materials such as minerals and stones that are used to mix materials such as concrete, marble, iron, steel, and glass (Deplazes, 2005). This study focuses on a material that is a hybrid between living material and a growing or planting medium (Trafton, 2014).

Mosses have a negative influence on building materials because they produce oxalic acid that can cause hydration in the material. Moss grows on historical buildings and causes erosion in the building materials. The erosion of building materials occurs due to the influence of weather and lack of maintenance (Lisci et al., 2003).

Research on overgrown moss on carved rocks in Wyoming showed that moss has both a negative effect (damage to the surface of material) and a positive effect (protection from rainwater and light) on the material. Positively, moss on the stone that provided by water and light become moss habitat, moss then fills cracks in the rock and indirectly coats the stone surface. Moss growth can be categorized as a negative value depending on the material properties - in this case, the size of the holes, which are directly proportional to the increasing porosity and absorption of water leading to cracking of the rock material (Chiari \& Cossio, 2004; Lisci et al., 2003).

\subsection{Ecological Architecture}

According to Yeang (2011), sustainable ecological architecture is architecture that is integrated with nature in all parts of building construction. Therefore, sustainable buildings consist of living and non-living material as components capable of forming ecosystems or maintaining existing habitats. Ecological architecture focuses on how ecological factors affect buildings, their inhabitants, and the surrounding environment, explaining the influence of ecological building design and its balance with nature. There are three components that influence ecological architecture, and one of them is an ecological element (technology and material) (Attmann, 2010). 


\subsection{Three Bryophytes}

Moss is included in the classification of fungi (ascomycetes and basidiomycetes) that live in symbiosis with photosynthetic organisms (cyanobacteria and green algae) (Hale, 1974). Host plants in a symbiotic process, such as fungi (mycobiont) and algae (phycobiont), help thallus growth in moss. Thallus is the root of moss that can grow in conditions where algae and fungi cannot survive (Lisci et al., 2003). The spread of moss occurs mostly through wind, birds, or insects. Moss can breed on a variety of substances such as tree trunks, dead wood, weathered wood, soil, and rocks (Windadri, 2009). Materials that are hollow, broken, or filled with holes that allow water to flow allow for moss to grow (Garty, 1992). That has led this research to study moss growth on cementitious material more deeply.

Generally, the optimum temperature needed for the development of moss is around $15-25^{\circ} \mathrm{C}$ and full sunlight intensity around 70,000-100,000 lux (Richards, 1984). Moss (bryophites) are divided into three classifications: Anthrocerotophyta, Marchantiophyta, and Bryophyta (Glime, 2013). Bryophites are more tolerant of dry air and shade than other classes of moss (Gradstein, 2001).

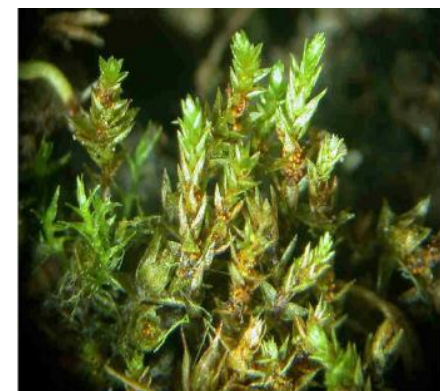

Bryum Apiculatum

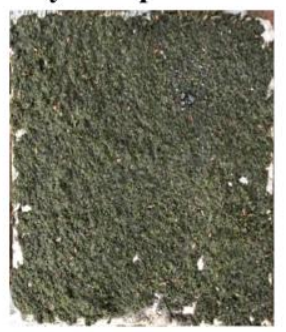

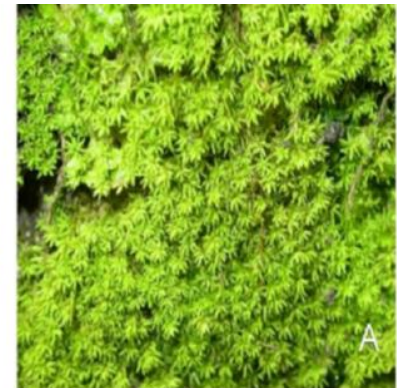

Barbula Indica



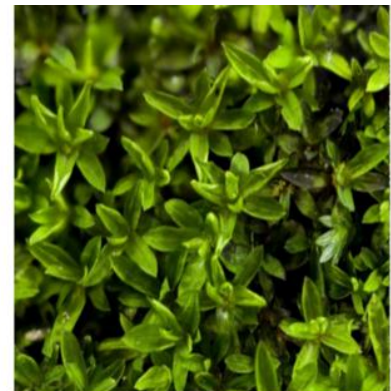

Hyophila Involuta

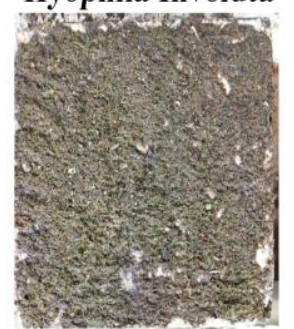

Figure 1 Three bryophyte mosses on the surface of concrete cubes

Three bryophite mosses chosen in this research were Bryum apiculatum, Barbula indica, and Hyophila involuta, which are commonly found growing on the surface of wet cementitious material (Putrika, 2015) (Figure 1). These mosses were planted by transplanting them onto the surface of concrete as a growing media. The surface of the concrete panels were conditioned before planting to support the moss growth. The next step was to gather moss and prepare the moss culture media for growing. Things to take into consideration before transplanting mosses were sunlight, a $\mathrm{pH}$ value between $5-5.5,60 \%$ moisture, and daily watering. The moss was mixed with yogurt and water, blending it into a slurry consistency and painting it on the concrete surfaces (Udawatha et al., 2018) as shown in Figure 2. 


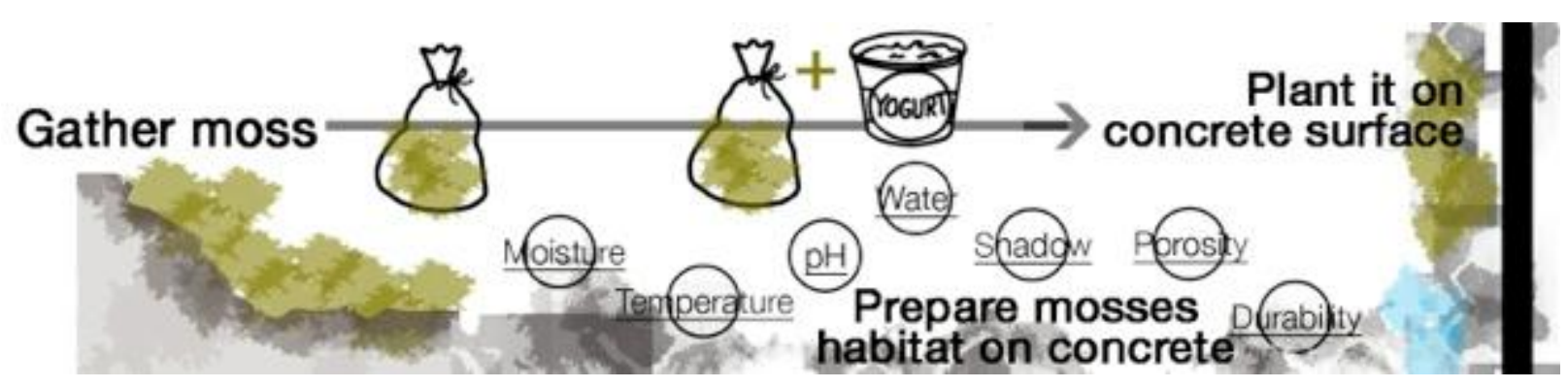

Figure 2 Process to plant the moss

\subsection{Three Concrete Mixtures}

Concrete is created by mixing cement, aggregate, water, and a low concentration of additional mixtures. The stirring process can be carried out on-site, or prefabricated material can be acquired in the form of blocks or other shapes (Berge, 2009). The mixtures of concrete in this study were chosen based on their potential as a growing media for moss. The mixtures were divided into three types: a mixture of Portland Cement concrete and two other mixtures of green concrete, which is more environmentally friendly. This research will focus on the K-175 standard as a non-structural construction of walls on the skin of buildings. K-175 has a 14-Mpa compressive strength on day 28 (ASTM C109).

Table 1 Concrete material codes

\begin{tabular}{|c|c|c|c|c|c|c|c|}
\hline \multirow[b]{2}{*}{$\begin{array}{l}\text { Sample } \\
\text { Code }\end{array}$} & \multirow[b]{2}{*}{ Trial Mix } & \multirow[b]{2}{*}{ Moss } & \multicolumn{4}{|c|}{ Quantities } & \multirow[b]{2}{*}{ Size } \\
\hline & & & $\begin{array}{c}\text { Day } \\
7\end{array}$ & Day 14 & $\begin{array}{c}\text { Day } \\
28\end{array}$ & $\begin{array}{l}\text { Day } \\
28\end{array}$ & \\
\hline $1 \mathrm{~A}$ & TM I - Fly ash & - & 3 & 3 & 3 & & \\
\hline $2 \mathrm{~A}$ & TM II - Concrete & - & 3 & 3 & 3 & & \\
\hline $3 \mathrm{~A}$ & TM III - Crushed brick & - & 3 & 3 & 3 & & $150 \times 150$ \\
\hline $1 \mathrm{AX}$ & TM I - Fly ash & Bryophite & & & & 3 & $\times 150 \mathrm{~mm}$ \\
\hline $2 \mathrm{AX}$ & TM II - Concrete & Bryophite & & & & 3 & \\
\hline $3 \mathrm{AX}$ & TM III - Crushed brick & Bryophite & & & & 3 & \\
\hline
\end{tabular}

Recycling industrial-waste products into concrete mixtures makes a more environmentally friendly material called green concrete (Baikerikar, 2014). Another definition of green concrete is an environmentally friendly concrete that is produced using a mixture of non- $\mathrm{CO}_{2}$ materials and/or non- $\mathrm{CO}_{2}$ production methods. The method most often used in producing green concrete is to use residual industrial production materials such as fly ash (Attmann, 2010). The mixtures of fly ash (TM 1) and crushed brick (TM III) were chosen based on previous research that found TM 1 could surpass 28-Mpa compressive strength (Berry et al., 2009) and TM III could surpass 21.5-Mpa compressive strength (Dawood \& Ramli, 2008) on day 28. Concrete material codes were used to make an easier definition variables (Table 1). The three mixtures of concrete in this research are shown in Table 2.

The methods of producing concrete can be seen in Figure 3. The most crucial dimension of the concrete panel is its thickness, due to the inner and outer systems that are associated with strength. The dimensions in this research are $50 \mathrm{~cm}(\mathrm{~W})$ and $8 \mathrm{~cm}(\mathrm{~T})$. The surfaces were designed to provide more comprehensive results. 
Table 2 Concrete mixtures

\begin{tabular}{|c|c|c|c|c|c|c|c|}
\hline \multirow{2}{*}{ Material Codes } & \multirow{2}{*}{$\begin{array}{l}\text { Density } \\
\left(\mathrm{kg} / \mathrm{m}^{3}\right)\end{array}$} & $\begin{array}{l}\text { Cement } \\
(\mathrm{kg})\end{array}$ & $\begin{array}{c}\text { Water } \\
(\mathrm{kg})\end{array}$ & $\begin{array}{c}\text { Fine Aggregates } \\
(\mathrm{kg})\end{array}$ & $\begin{array}{c}\text { Coarse } \\
\text { Aggregates } \\
(\mathrm{kg})\end{array}$ & $\begin{array}{c}\text { Crushed } \\
\text { Brick }\end{array}$ & $\begin{array}{c}\text { Additional } \\
\text { Mixtures } \\
(\mathrm{kg})\end{array}$ \\
\hline & & PC 1 & - & $\begin{array}{c}\text { Natural } \\
\text { Galunggung } \\
\text { Sand } \\
\end{array}$ & Split Stone & - & Fly Ash F \\
\hline Trial Mix I - [TM I] & 2401 & 200 & 160 & 616 & 1225 & & 200 \\
\hline Trial Mix II - [TM II] & 2400 & 274 & 190 & 784 & 1152 & & \\
\hline Trial Mix III - [TM III] & 2120 & 360 & 160 & 900 & & 700 & \\
\hline
\end{tabular}

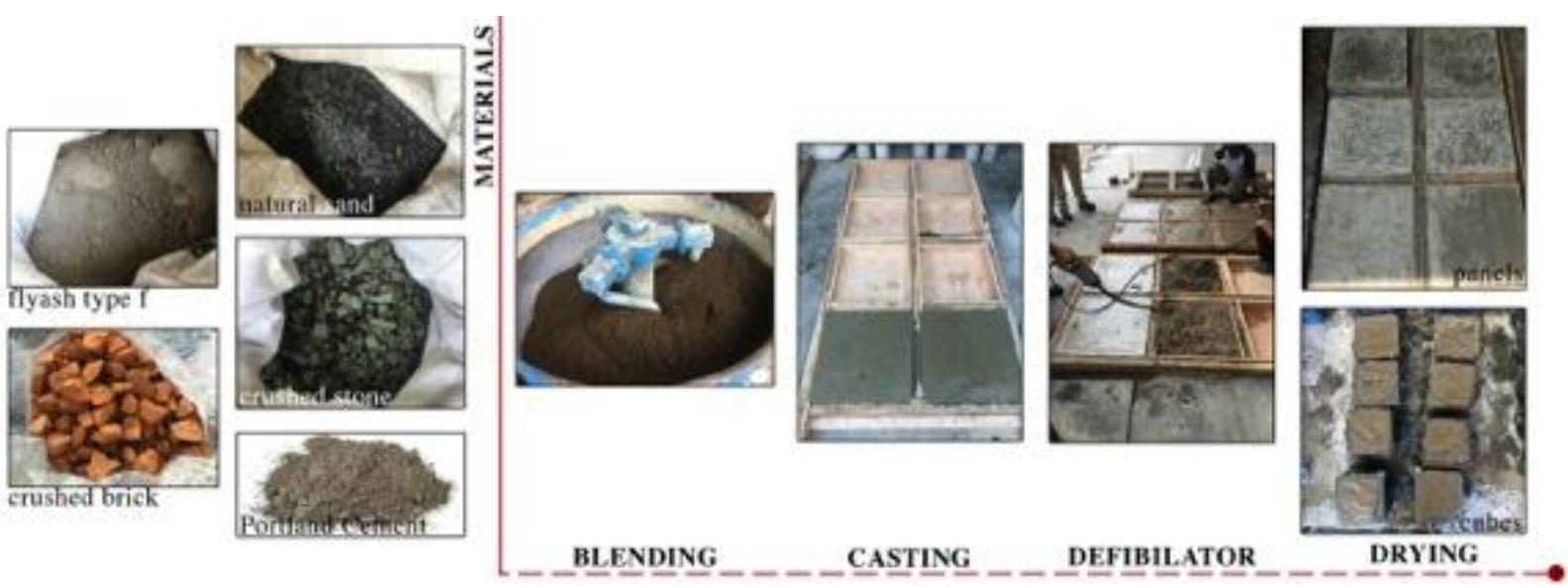

Figure 3 Methods of producing concrete panels and cubes

\subsection{Standard Methods Used}

Tension tests were conducted based on the American Standard Test Method C109. Three bryophyte mosses were planted on nine concrete panels and twenty-seven sample cubes. To obtain concrete and its mechanical properties, tension tests were conducted by using 27 cubes $15 \mathrm{~cm}$ on each side. The cubes were tested on days 7 and 14 without moss. Another nine cubes with moss were tested on day 28 . The pre-vegetated concrete cubes were compared to the nonpre-vegetated concrete cubes based on the standard of concrete that gains its maximum tension on day 28.
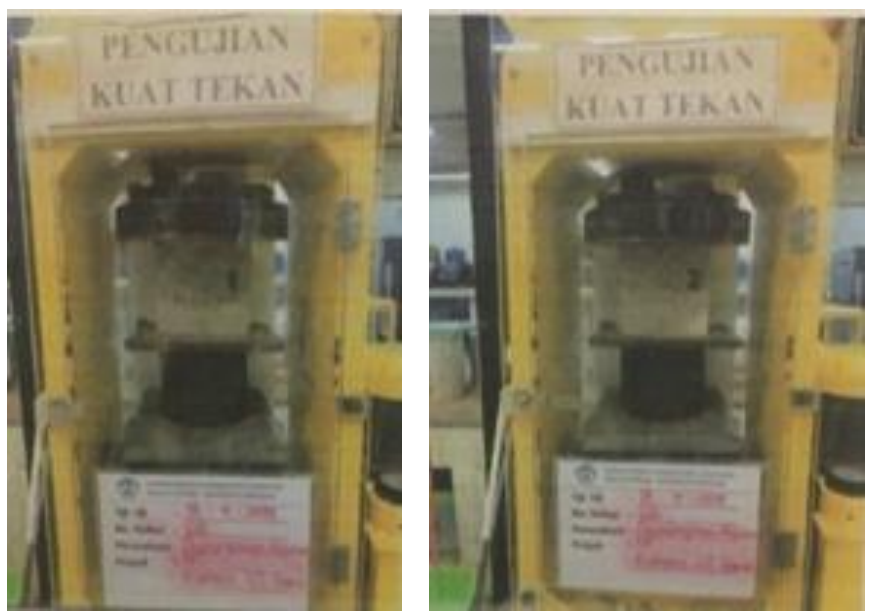

Figure 4 Compressive strength test machine 


\subsection{Moss Growth Measurement}

Moss cubes were sorted into a three-by-three, vertical-horizontal position on a suitable space found near the moss was taken at the Department of Architecture Universitas Indonesia (Figure $5)$.

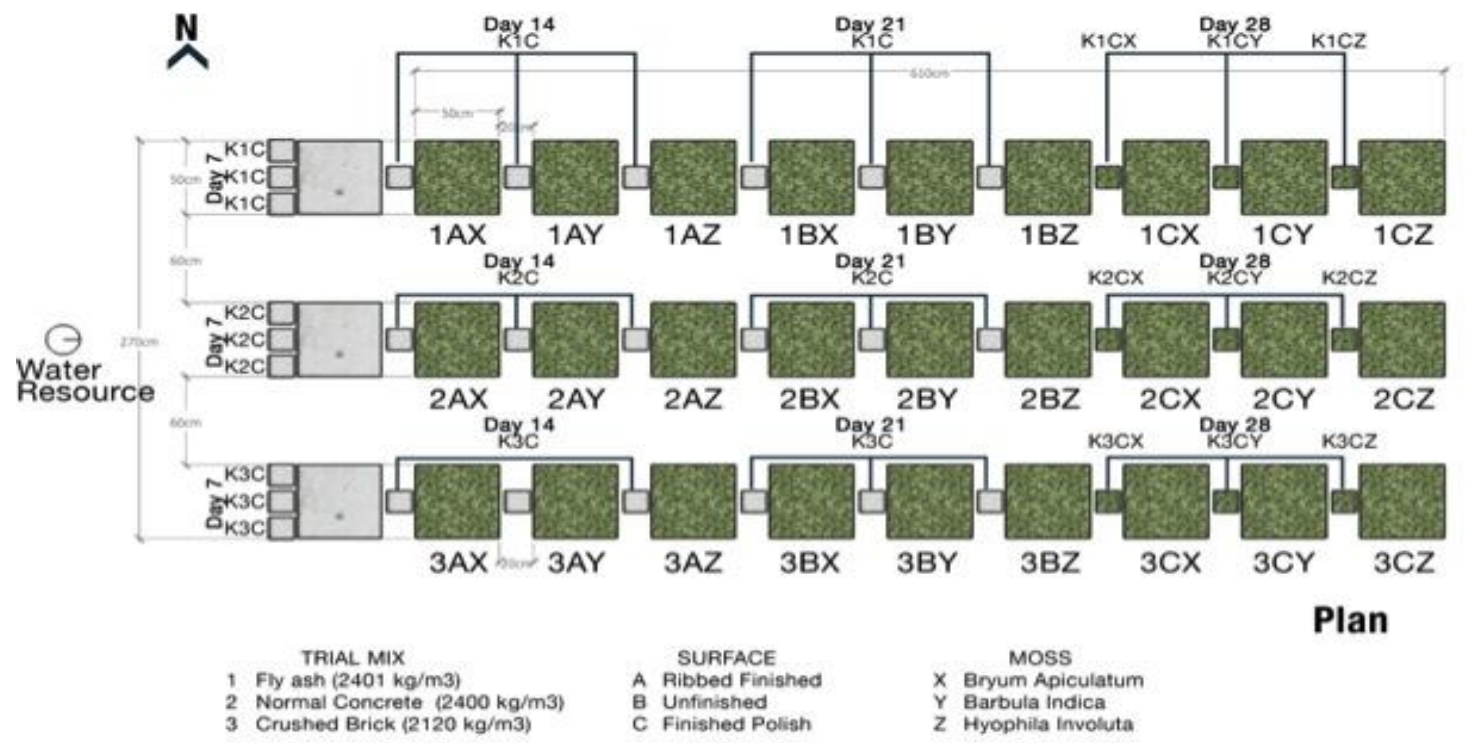

Figure 5 Position of concrete panels in the research area

One consideration in choosing the research area was the suitability of the environment to support moss growth. Moss growth on the concrete panels was calculated on days 1, 7, 14, 21, and 28. Nine panel cubes were compared in one graph to show the moss growth on the 1st and 28th days and the difference between the two. The calculation of the height on day 28 height minus the height on day 1 showed that the concrete cubes with the lowest difference were $3 \mathrm{AY}$, 3AZ, 3BX, and 2AZ (Table 3).

Suitable mixtures for moss were those made with crushed brick and normal concrete. Crushed brick is a material that often overgrown by moss as well as water-absorbing material. Normal concrete panels can be a planting medium for moss due to their $\mathrm{pH}$ properties, which are suitable for growing moss and, when compared with concrete panels made from fly ash, have a more acidic $\mathrm{pH}$ and closed concrete pores.

The surface with a ribbed finished can hold more water than an unfinished surface, because there is a pore gap for the water to stay and puddling. This causes concrete panels to last longer in moisture so that moss can grow. The type of moss that survived the best in the four panels was the Hyophila involuta species, because it is more often found growing on rocks based on previous research (Putrika, 2015).

Table 3 Calculation of moss growth difference

\begin{tabular}{|c|c|c|c|c|c|}
\hline No. & Panel & Concrete Mixtures & $\begin{array}{l}\text { Finished } \\
\text { Surface }\end{array}$ & Moss Species & $\begin{array}{c}\text { Difference in Surface } \\
\text { Area }\left(\mathrm{cm}^{2}\right)\end{array}$ \\
\hline 1 & $3 \mathrm{AY}$ & $\begin{array}{l}\text { Crushed brick concrete } \\
\text { panel - TM III }\end{array}$ & Ribbed finished & Hyophila involuta & -5.5 \\
\hline 2 & $3 \mathrm{AZ}$ & $\begin{array}{l}\text { Crushed brick concrete } \\
\text { panel - TM III }\end{array}$ & Ribbed finished & Hyophila involuta & -6 \\
\hline 3 & $2 \mathrm{BX}$ & Concrete panel - TM I & Ribbed finished & Bryum apiculatum & -11 \\
\hline 4 & $2 \mathrm{AZ}$ & Concrete panel - TM I & Unfinished & Barbula indica & -25 \\
\hline
\end{tabular}




\section{RESULTS AND DISCUSSION}

All non-pre-vegetated concrete tested had a compressive strength significantly higher on day 7 compared with the K-175 standard on the same day. The compressive strength increased until day 28. All pre-vegetated concrete had a compressive strength lower than the non-pre-vegetated concrete.

\subsection{Compressive Strength of Trial Mix I}

The maximum strength of TM I was 33.15 Mpa on day 28. Previous studies have found that TM I can reach 27.6 Mpa on day 28 (Berry et al., 2009). The current test showed that the prevegetated concrete panel of TM I on day 28 had a lower result than the non-pre-vegetated concrete panel, which had 29.84 Mpa (Figure 6).

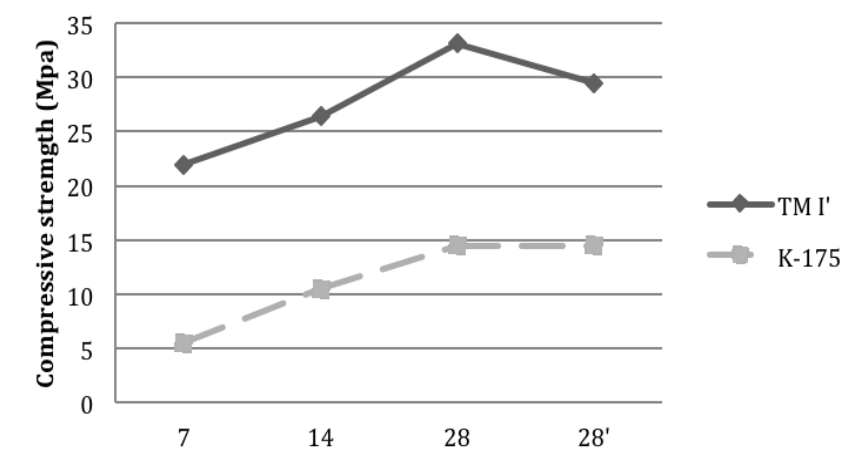

Figure 6 Graphic of compressive strength results of non-pre-vegetated and pre-vegetated concrete cubes using Trial Mix I on days 7, 14, and 28

\subsection{Compressive Strength of Trial Mix II}

The maximum strength value of TM II on day 28 was $26.68 \mathrm{Mpa}$. Previous studies have found that TM II can reach 14.5 Mpa on day 28 (ASTM C109). The current test showed that the prevegetated concrete panel of TM II had a lower result on day 28 than the non-pre-vegetated concrete panel, which had 21.74 Mpa (Figure 7).

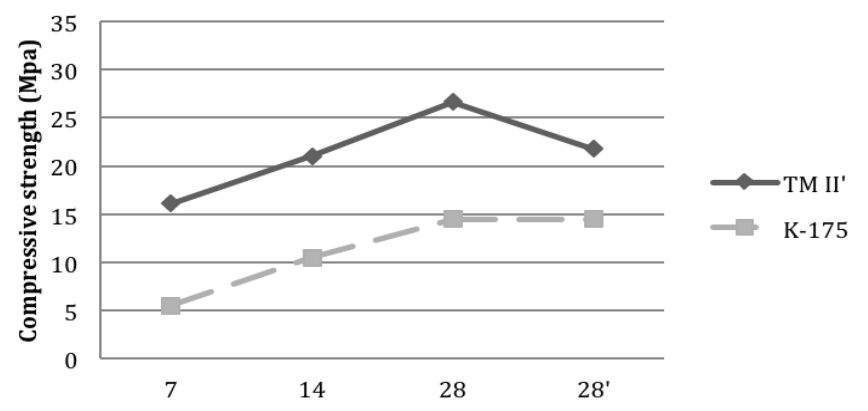

Figure 7 Graphic of compressive strength results of non-pre-vegetated and pre-vegetated concrete cubes using Trial Mix II on days 7, 14, and 28

\subsection{Compressive Strength of Trial Mix III}

The maximum strength value of TM III on day 28 was 26 Mpa. Previous studies have found that TM III can reach 14.5 Mpa on day 28 (Dawood \& Ramli, 2008). The current test showed that the pre-vegetated concrete panel of TM III had a lower result on day 28 than the non-prevegetated concrete panel, which had 21.74 Mpa (Figure 8). 


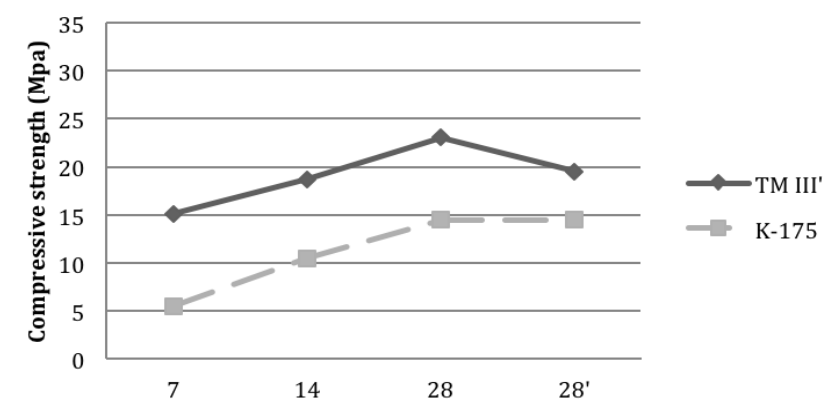

Figure 8 Graphic of compressive strength results of non-pre-vegetated and pre-vegetated concrete cubes using Trial Mix III on days 7, 14, and 28

\subsection{Discussion}

As a non-structural construction, all mixtures of pre-vegetated concrete panels tested showed that pre-vegetated concrete panels have results comparable to the non-pre-vegetated concrete panels. TM I had the highest tension result among all the mixtures. TM I also reached the highest tension result compared to the standard of K-175 (Figure 9). The compressive strength of TM I was three times higher than TM III followed by TM II (Figure 6).

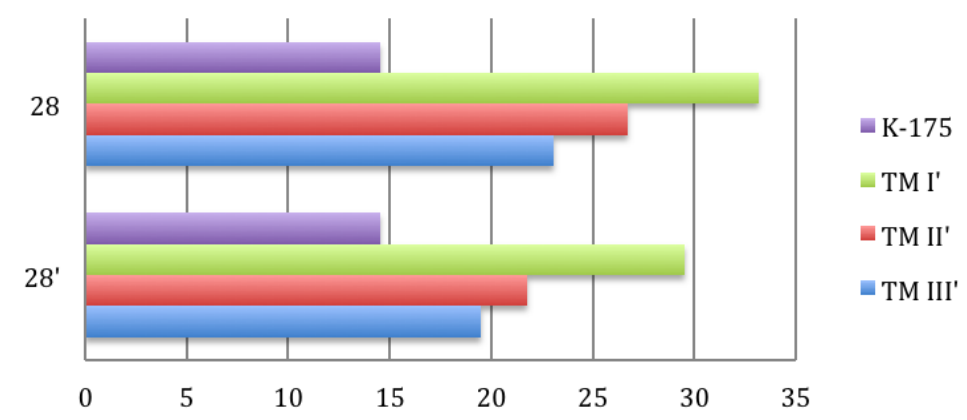

Figure 9 Compressive strength comparison of standard K-175 and trial mixes

Comparison between pre-vegetated panels and the standard shows that TM I had a difference of 18.65, TM II had a difference of 12.18, and TM III had a difference of 8.52 when comparing their compressive strengths to the 14.5-Mpa standard of K-175. The results show that TM I had the highest compressive strength.

Comparison between non-pre-vegetated panels and the standard shows that TM I had a difference of 14.98, TM II had a difference of 7.24, and TM III had a difference of 8.52 when comparing their compressive strengths to the 14.5-Mpa standard of K-175. The results show that TM I had the highest compressive strength here as well.

The results show that vegetation growing on concrete decreases its tension performance. Previous research found that vegetation growing on historical buildings and ruins may be picturesque but is also one of the main reasons for their deterioration, because the roots may penetrate deep into the structure and grow to a large size, causing physical and chemical damage (Dia \& Not, 1991). 
Table 4 Compressive strength test results of TM I, II, and III

\begin{tabular}{|c|c|c|c|c|c|c|c|c|c|c|c|c|c|c|}
\hline \multirow{3}{*}{$\begin{array}{l}\text { Material } \\
\text { Codes }\end{array}$} & \multirow{3}{*}{$\begin{array}{c}\text { Density } \\
\rho \\
\mathrm{Kg} / \mathrm{m}^{3}\end{array}$} & \multirow{3}{*}{$\begin{array}{c}\text { Standard } \\
\text { f'c }^{\prime} \\
\text { Mpa } \\
28 \text { days }\end{array}$} & \multicolumn{12}{|c|}{ Compressive strength } \\
\hline & & & \multicolumn{3}{|c|}{$\begin{array}{c}\mathrm{f} 7 \\
\mathrm{Mpa} \\
\end{array}$} & \multicolumn{3}{|c|}{$\begin{array}{l}\text { f } 14 \\
\text { Mpa }\end{array}$} & \multicolumn{3}{|c|}{$\begin{array}{l}\text { f } 28 \\
\text { Mpa }\end{array}$} & \multicolumn{3}{|c|}{$\begin{array}{l}\text { f 28' } \\
\text { Mpa }\end{array}$} \\
\hline & & & A & $\mathrm{B}$ & $\mathrm{C}$ & $\mathrm{A}$ & $\mathrm{B}$ & $\mathrm{C}$ & $\mathrm{A}$ & $\mathrm{B}$ & $\mathrm{C}$ & $\mathrm{A}$ & $\mathrm{B}$ & $\mathrm{C}$ \\
\hline$\overline{\text { Trial }}$ & 2400 & & 23.69 & 20.3 & 21.8 & 25.52 & 26.35 & 27.37 & 34.52 & 32.92 & 32.02 & 31.5 & 29.2 & 27.76 \\
\hline Mix 1 & & & & 21.39 & & & 26.41 & & & 33.15 & & & 29.48 & \\
\hline Trial & 2401 & 145 & 13.7 & 17.49 & 16.97 & 23.44 & 20.21 & 19.43 & 26.7 & 26 & 27.35 & 22.33 & 21.22 & 21.67 \\
\hline Mix 2 & & 14.5 & & 16.07 & & & 21.02 & & & 26.68 & & & 21.74 & \\
\hline Trial & 2210 & & 14.06 & 17.54 & 13.99 & 17.46 & 18.8 & 19.85 & 21.92 & 23.94 & 23.22 & 18.24 & 20.54 & 19.53 \\
\hline Mix 3 & & & & 15.19 & & & 18.7 & & & 23.02 & & & 19.43 & \\
\hline
\end{tabular}

\section{CONCLUSION}

The present work characterizes the performance of pre-vegetated and non-pre-vegetated concrete panels. The study utilized the concrete standard for characterization, which allows for a comparison to pre-vegetated concrete. The results of the study indicate that pre-vegetated concrete panels have properties that compare with or surpass that of non-pre-vegetated concrete panels as nonstructural concrete. Among three trial mixes chosen, it was found that TM I (a mixture of fly ash) had the highest compressive strength on pre-vegetated and non-prevegetated concrete panels. In conclusion, as a nonstructural concrete panel, all the trial mixes matched the standard of K-175, surpassing $14.5 \mathrm{Mpa}$ in compressive strength. Further investigation is needed to provide a wide range of structural concrete that can be used in prevegetated concrete panels.

\section{ACKNOWLEDGEMENT}

The authors gratefully acknowledge the Research and Development Division of Wika Beton Inc. for their support on the concrete panels, samples, and funding of the research project.

\section{REFERENCES}

ASTM C109 / C109M-16a, Standard Test Method for Compressive Strength of Hydraulic Cement Mortars (using 2-in. or [50-mm] Cube Specimens), ASTM International, West Conshohocken, PA, 2016, Available Online at https://www.astm.org/Standards/C109

Attmann, O. 2010. Green Architecture: Advanced Technologies and Materials. McGraw-Hill: New York.

Baikerikar, A., 2014. A Review on Green Concrete. Journal of Emerging Technologies and Innovative Research (JETIR), Volume 1(6), pp. 472-474

Berge, B., 2009. The Ecology of Building Materials. $2^{\text {nd }}$ Edition, Burlington, MA: Elsevier

Berry, M., Cross, D., Stephens, J., 2009. Changing the Environment: An Alternative "Green" Concrete Produced without Portland Cement. In: 2009 World of Coal Ash (WOCA) Conference

Chiari G., Cossio R., 2002. Ethyl Silicate Treatment's Control by Image Treatment Procedure, in I Silicati Nella Conservazione: Indagini, Esperienze e Valutazioni per il Consolidamento dei Manufatti Storici, ed Appolonia L., editor. (Torino: Associazione Villa dell'arte), pp. $147-156$

Chiari G., Cossio R., 2004. Lichens on Wyoming Sandstone: Do They Cause Damage? In Biodeterioration of Stone Surfaces: Lichens and Biofilms as Weathering Agents of Rocks and Cultural Heritage, ed. L.L. St. Clair and M.R.D. Seaward, pp. 99-114, Dordrecht, Netherlands, and London: Kluwer Academic Publishers

Dawood, E.T., Ramli, M., 2008. Rational Mix Design of Lightweight Concrete for Optimum Strength. In: $2^{\text {nd }}$ International Conference on Built Environment in Developing Countries (ICBEDC 2008) 
Deplazes A., 2005. Constructing Architecture Materials Processes Structures. Birkhäuser Publishers for Architecture, Berlin

Dia, M.G., Not, R., 1991. Gli Agenti Biodeteriogeni Degli Edifici Monumentali Del Centro Storico Della Città di Palermo. Quaderni di Botanica Ambientale Applicata, Volume 2, pp. $3-10$

Farelly L, 2009. Construction+materiality. AVA Publishing SA, Lausanne

Garty, J., 1992. The Postfire Recovery of Rock-inhabiting Algae, Microfungi and Lichens. Canadian Journal of Botany, Volume 70, pp. 301-312

Glime, J.M., 2013. Bryophyte Ecology Volume 1: Physiological Ecology. Michigan Technological University, Michigan

Gradstein, S.R., 2011. Guide to the Liveworts and Hornwors of Java. Seameo Biotrop, Bogor, Indonesia

Hale, M. E., 1974. The Biology of Lichens. $2^{\text {nd }}$ Edition. London: Arnold

Johnston, J., Newton, J., 1993. Building Green: A Guide for Using Plants on Roofs, Walls, and Pavements. The London Ecology Unit, London

Kiran, C., Mamata, P., Raghunathan, M., 2005. Understanding Environment. Sage Publications, London.

Lisci, M., Monte, M., Pacini, E., 2003. Lichens and Higher Plants on Stone: A Review. International Biodeterioration \& Biodegradation, Volume 51(1), pp. 1-17

Mansor, M., Zakariya, K., Harun, N.Z., Bakar, N.I.A., 2017. Appreciation of Vertical Greenery in a City as a Public Art. Journal of the Malaysian Institute of Planners, Volume 15(1), pp. $117-128$

Ord, C., 2017. Town Councillor Suggests 'Living Wall' for Newbury 'Eyesore'. Available online at http://www.newburytoday.co.uk/news/home/22491/town-councillor-suggestsliving-wall-for-newbury-eyesore.html, Accessed on October $16^{\text {th }}, 2017$

Putrika, A., 2015. Epifit Moss Community at Universita Indonesia. Master's Thesis, Graduate Program, Universitas Indonesia, Depok, Indonesia

Rakhshandehroo, M., Yusof, M.J.M., Arabi, B.R., 2015. Living Wall (Vertical Greening): Benefits and Threats. Applied Mechanics and Materials, Volume. 747, pp. 16-19

Richards, P. W., 1984. The Ecology of Tropical Forest Bryophytes. $2^{\text {nd }}$ Edition, Cambridge University Press, Cambridge

Trafton, A., 2014. Engineers design 'living materials'. Available Online at http://news.mit.edu/2014/engineers-design-living-materials, Accessed on September $14^{\text {th }}, 2017$

Udawatha, C., Galkanda, H., Ariyarathne, I.S., Jayasinghe, G.Y., Halwatura, R., 2018. Mold Growth and Moss Growth on Tropical Walls. Building and Environment, Volume 137, pp. 268-279

Yeang, K. 2011. EcoArchitecture: The Book of Ken Yeang. John Wiley \& Sons: New Jersey.

Waldi, R., 2017. Mosses Inventorisation in Lampung Rubber Forest. Bachelor's Thesis, Graduate Program, University Islam Negeri Raden Intan, Lampung, Indonesia.

Windadri, F.I., 2009. Keragaman Lumut pada Marga Pandanus di Taman Nasional Ujung Kulon, Banten (Diversity of Moss Pandanus Venus at National Garden Ujung Kulon, Banten). Jurnal Natur Indonesia, Volume 11(2), pp. 89-93 